\title{
Prediction of Bitter Pit in 'Honeycrisp' Apples and Best Management Implications
}

\author{
Tara Auxt Baugher ${ }^{1}$ \\ The Pennsylvania State University, Cooperative Extension in Adams County, \\ 670 Old Harrisburg Road, Gettysburg, PA 17325
}

\author{
Richard Marini \\ Department of Plant Science, The Pennsylvania State University, 119 Tyson \\ Building, University Park, PA 16802
}

\section{James R. Schupp}

Fruit Research and Extension Center, The Pennsylvania State University, 290 University Drive, Biglerville, PA 17307

\section{Christopher B. Watkins}

School of Integrative Plant Science, Cornell University, Plant Science Building, Ithaca, NY 14853

Additional index words. Malus $\times$ domestica, calcium disorders, prediction of postharvest disorders, apple peel analysis, mineral nutrition

\begin{abstract}
During a 3-year study of bitter pit in commercial 'Honeycrisp' apple (Malus $\times$ domestica) orchards, incidence was associated with low calcium (Ca) levels in fruit peel; high ratios of nitrogen $(\mathrm{N})$, potassium $(\mathrm{K})$, and/or magnesium $(\mathrm{Mg})$ to $\mathrm{Ca}$ in fruit peel; excessive terminal shoot length; and low crop load. Peel $\mathrm{N}$ and $\mathrm{Mg}$ concentrations were negatively correlated and peel Ca concentration positively correlated with crop density (CD). Shoot length (SL) was not consistently correlated with peel $\mathrm{N}, \mathrm{Mg}$, or phosphorus (P) and was negatively correlated with only Ca. A two-variable model that included SL and the ratio of $\mathrm{N}$ to $\mathrm{Ca}$ explained more than $65 \%$ of bitter pit incidence. The model has implications for best management of the cultivar in the field and during storage.
\end{abstract}

The high susceptibility of 'Honeycrisp' to bitter pit is not well understood. Crassweller and Smith (2016) found levels of Ca in foliar tissue were lower in 'Honeycrisp' than in

Received for publication 10 July 2017. Accepted for publication 21 Aug. 2017.

This research was supported by the State Horticultural Association of Pennsylvania, the Pennsylvania Apple Program, and the Pennsylvania Department of Agriculture Research Program.

We acknowledge the valuable contributions of Tom Jarvinen, Michael Basedow, Erin Dugan, Kristi Kraft, Danielle Ryan, Montserrat Fonseca Estrada, Alana Anderson, Ryan Hilton, Sladjana Prozo, and Gustavo Salazar (Penn State Extension); Tom Kon, Edwin Winzeler, and Melanie Schupp (Penn State Fruit Research and Extension Center); Dave and Jim Benner, Clint and Bill Lory, Ben and Joe Lerew, Chris Baugher, and Dave and John Wenk (grower cooperators); Lee Showalter, Leighton Rice, David Rice, Ben Rice (Rice Fruit Company); Ryan Hess (Hess Brothers Fruit Company); John Spargo, and Denyce R. Matlin (Penn State Agricultural Analytical Services Laboratory); and Jacqueline F. Nock and Yosef Al Shoffe (Cornell Apple Postharvest Physiology Laboratory). The mention of a trademark, proprietary product, or vendor does not constitute a guarantee or warranty of the product and does not imply its approval to the exclusion of other products or vendors that also may be suitable.

${ }^{1}$ Corresponding author. E-mail: tab36@psu.edu.
$\mathrm{Ca}$ treatments were required for reducing bitter pit incidence in 'Honeycrisp' grown in New York. Bitter pit control was not enhanced by supplementing $\mathrm{Ca}$ sprays with trifloxystrobin fungicide, boron, or harpin protein treatments. Trials by Biggs and Peck (2015) showed that rates ranging as high as $26.3 \mathrm{~kg} \cdot \mathrm{ha}^{-1}$ per season of elemental Ca were needed to significantly reduce bitter pit incidence in 'Honeycrisp' apples grown in Virginia and West Virginia orchards. Foliar $\mathrm{Ca}$ products were evaluated in both studies, and none were better than calcium chloride $\left(\mathrm{CaCl}_{2}\right)$. Telias et al. (2006) reported that crop load had a more significant effect on bitter pit than $\mathrm{Ca}$ sprays, with bitter pit incidence being positively correlated to low yield and large fruit. Mitcham (2008) and Silveira et al. (2012) demonstrated that shoot growth suppression reduced bitter pit incidence. Research results reported by other investigators on the effects of $\mathrm{Ca}$, crop load (CD), and shoot growth have at times been contradictory, and predictive tools are needed to assist producers in developing site-specific best management programs for managing bitter pit.

Fruit mineral analysis has the potential to assist producers in managing nutrient imbalances in the orchard while also providing a possible predictive tool. In research by Ferguson et al. (1979), low Ca in 'Cox's Orange Pippin' fruit sampled 3 weeks before harvest was associated with an increased risk of bitter pit development. Amarante et al. (2013), De Freitas et al. (2015), Dris et al. (1998), Ferguson and Watkins (1989), and Lanauskas and Kvikliene (2006) suggested high $\mathrm{N}, \mathrm{K}$, and/or $\mathrm{Mg}$ to $\mathrm{Ca}$ ratios in fruit of bitter pit-prone cultivars could improve the prediction of susceptibility to the disorder. Al Shoffe et al. (2014) reported significant correlations between bitter pit and levels of $\mathrm{N}, \mathrm{P}, \mathrm{K}, \mathrm{N} / \mathrm{Ca}, \mathrm{Mg}$, and $(\mathrm{Mg}+\mathrm{N}) / \mathrm{Ca}$ ratio in 'Honeycrisp' fruit.

The fruit tissue sampling procedure affects the reliability of bitter pit prediction from mineral analysis, and Amarante et al. (2013) demonstrated tissue should be sampled from the calyx end of the fruit. The best tissue to sample from 'Fuji' was the peel, whereas the flesh was a better predictor for 'Caterina'. Before the research reported in this article, the authors compared peel and flesh nutrient measurements for 'Honeycrisp' and found improved correlations to bitter pit with nutrients measured in peel tissues (Baugher et al., 2014). We also found peel tissues could be prepared by air-drying rather than freeze-drying, which made the technique more practical for commercial growers (unpublished data).

The objectives of a 3-year study of 'Honeycrisp' grown at three crop densities in six commercial orchards were to

1. improve guidelines for balancing $\mathrm{CD}$, terminal SL, and fruit nutrient levels to reduce bitter pit incidence in 'Honeycrisp' orchards and 
2. develop predictive models for determining how to improve management and postharvest handling of 'Honeycrisp' apples.

Packinghouses in major fruit growing regions use various fruit nutrient models to predict the potential for bitter pit in storage (Ferguson, 2001; Hanson, 2012). This investigation was designed to assess both field measurements and fruit nutrient measurements with the objective of developing a model that would guide both fruit producers and fruit packers.

\section{Materials and Methods}

Field trial design. During 2014 to 2016, uniform field trials were established in six high-density 'Honeycrisp' blocks in orchards with varying histories of bitter pit incidence. The studies included two orchard blocks each with histories of high, moderate, and low levels of bitter pit. The six blocks were the same each year with the exception of a change in 2016 because of two blocks (history of low bitter pit) receiving hail damage. At the start of the project, the trees ranged in age from 5- to 8-year old, and no prohexadione-calcium was applied to suppress shoot growth in any of the blocks or years.

Within each block, three trees each were selected with high, medium, and low crop loads. Individual trees were handled as replications, and the following data were collected:

1. Trunk diameter at a 20-cm height and the number of fruit at harvest for determinations of $\mathrm{CD}$ (fruit $/ \mathrm{cm}^{2}$ trunk cross-sectional area);

2. Average SL calculated from 10 representative terminal shoots per tree after terminal bud set;

3. Fruit peel nutrient levels at 3 weeks before harvest (composite sample from 15 randomly selected fruit of similar size per tree);

4. Average fruit weight, soluble solids concentration, and flesh firmness at harvest (five representative fruit per tree); and

5. Bitter pit incidence at harvest and again following long-term storage (the percentage of 20 randomly selected fruit of similar size per tree with bitter pit symptoms).

Fruit tissue preparation and analysis. Selection of the fruit tissue to sample was based on a 2012 preliminary study in which bitter pit incidence was more closely correlated to minerals in fruit peel than in fruit tissue (Baugher et al., 2014). Based on research by Amarante et al. (2013), 1-cm wide peel samples were taken from around the circumference at the calyx end of the fruit, using a potato peeler and exercising care to prevent removal of fruit flesh. Fruit peel samples were air-dried and then ground into a fine powder. Analyses for N, P, K, Ca, Mg, $\mathrm{Mn}, \mathrm{Fe}, \mathrm{Cu}, \mathrm{B}$, and $\mathrm{Zn}$ were conducted by the Penn State Agricultural Analytical Services Laboratory (procedures described at http:// agsci.psu.edu/aasl/plant-analysis/plant-methods; Penn State College of Agricultural Sciences, 2017).

Bitter pit assessment. Fruit samples were collected at optimum maturity for long-term storage based on ground color and starch measurements (Blanpied and Silsby, 1992; Greene et al., 2015). The samples were stored at the Penn State Fruit Research and Extension Center, Biglerville, PA, in air storage maintained at $3.3^{\circ} \mathrm{C}$. Fruit were assessed for the incidence of bitter pit after 4 months in storage plus $7 \mathrm{~d}$ at $20^{\circ} \mathrm{C}$.

Statistical analysis. Relationships between variables of the study were first evaluated as scatter plots with SAS's PROC GPLOT and G3D before using PROC CORR (Freund and Littell, 2000) to verify the linear relationships between the response variable (percentage of fruit with bitter pit symptoms after storage) and 21 potential regressor variables [average SL $(\mathrm{cm}), \mathrm{CD}$ (fruit $/ \mathrm{cm}^{2}$ trunk cross-sectional area)], N, P, K, Ca, Mg, S, $\mathrm{Mn}, \mathrm{Fe}, \mathrm{B}, \mathrm{Cu}, \mathrm{Al}, \mathrm{Zn}, \mathrm{Na}, \mathrm{N} / \mathrm{Ca}, \mathrm{K} / \mathrm{Ca}, \mathrm{Mg} /$ $\mathrm{Ca},(\mathrm{Mg}+\mathrm{K}) / \mathrm{Ca},(\mathrm{Mg}+\mathrm{K}+\mathrm{N}) / \mathrm{Ca},[(\mathrm{Mg}+\mathrm{K}$ $+\mathrm{N}) / \mathrm{Ca}]-38$ (referred to as the "accumulated ratio"), and $\{[(\mathrm{Mn}+\mathrm{N}) / \mathrm{Ca}]+(\mathrm{Mg} / \mathrm{Ca})$ $+[\mathrm{Mg} /(\mathrm{Ca}+(\mathrm{Mg}+\mathrm{K})) / \mathrm{Ca}]\}$. The accumulated ratio was included as a variable because it is a fruit nutrient model (developed by Harold Ostenson; Hanson, 2012) used by Washington packers to segregate fruit by storage potential. PROC REG was used to develop multiple regression models for each year following the same approach. Because the models developed for each year were not similar, the data for all three years were combined to identify a subset of variables for a predictive model.

The combined data set with 162 observations was split by randomly assigning twothirds of the observations to a "training" data set and the remaining 54 observations as a "validation" data set. For comparative purposes, models were obtained for the training data set with the FORWARD selection, BACKWARD elimination, STEPWISE selection, and MAXR maximum $R$-square improvement methods. These methods are easily performed, and they usually identify good models based on the selection criteria, but they rarely identify the best model (Myers, 1990). Therefore, the best model was identified using the RSQUARE option in the model statement to generate all possible onevariable, two-variable, three-variable,..., 19-variable models. Criteria considered for model selection included the coefficient of determination $\left(R^{2}\right)$, adjusted $R^{2}$, Mallow's conceptual predictive criteria $\left(C_{\mathrm{p}}\right)$, mean square error (MSE), Akaike information criterion (AIC), and prediction sum of squares. Values of the $C_{\mathrm{p}}$ statistic indicated that a model with six- or seven-variables would prevent overfitting. The three best seven-variable models contained similar subsets of variables including SL, plus combinations of ten variables $(\mathrm{P}, \mathrm{Mg}, \mathrm{K}, \mathrm{S}$, $\mathrm{Zn}$ and the ratios of N/Ca, K/Ca, $\mathrm{Mg} / \mathrm{Ca},(\mathrm{Mg}+$ $\mathrm{K}) / \mathrm{Ca}$, and accumulated ratio. All of these models had $R^{2}$ values of $0.701-0.704$ and adjusted $R^{2}$ values of $0.680-0.683$. A model was fit with all 11 of these regressor variables, and the $R$, INFLUENCE, VIF, and COLLINOINT options were requested to provide model diagnostics. Based on values of the influence statistics (Hat Diagonal statistic, Cov Ratio statistic, DFFITS, and DFBETAS), one observation was identified as influential and was deleted from the data set. The eigenvalues, variance inflation index, condition index, and proportion of variation values indicated that the predictor variables were not collinear. Although scatter plots and partial leverage plots did not indicate the need for including quadratic terms in the model, quadratic terms for each variable were included in the model and manual backward elimination was used to remove variables from the model that were not significant $(P>0.05)$. Two-way interaction terms were also created and added to the model and nonsignificant $(P>0.05)$ variables were eliminated from the model by manual backward elimination.

The best model contained the terms SL, $\mathrm{N}, \mathrm{Ca}, \mathrm{Ca}^{2}, \mathrm{Mn}$, and $\mathrm{Ca} * \mathrm{~N}$ (all variables were significant at the $5 \%$ level, $R^{2}=0.7251$, Adjusted $R^{2}=0.7086$ ). A slightly simpler model contained the terms SL, N, Ca, $\mathrm{Ca}^{2}$, and $\mathrm{Ca} * \mathrm{~N}\left(R^{2}=0.7148\right.$, Adjusted $R^{2}=$ 0.7007). A much simpler model that explained nearly as much variation contained just two variables, $\mathrm{SL}$ and N/Ca $\left(R^{2}=0.6805\right.$, Adjusted $R^{2}=0.6765$ ). Based on the adjusted $R^{2}$, the more complicated model explained only $2.4 \%$ more variation, so we chose the two-variable model as the best model.

To validate the training model, the validation data set was used to fit a model using the FORWARD selection and RSQUARE options in PROC REG and the same twovariable model was again selected $\left(R^{2}=\right.$ 0.6605 , Adjusted $R^{2}=0.6472$ ). To further cross-validate the model, the regression equation estimated from the training model was used to predict values of BP using the same model for the validation data set. Using PROC REG, the parameter estimates were output to a new data set and used as scoring coefficients with PROC SCORE (Freund and Littell, 2000). The new data set containing the original data set plus the predicted values was used to plot the actual values against the predicted values to visually evaluate how well the model fit the data. PROC GLMSELECT (Cohen, 2006) was also used to validate the model using all 19 regressor variables. By including VALIDATE $=0.30$ in the PARTITION statement, $30 \%$ or 48 observations randomly selected from the original data set of 162 observations were assigned to the validation data set. Models were fit with the FORWARD and STEPWISE SELECTION options with STOP = VALIDATE. In addition, the model was also fit with the LASSO SELECTION. All three methods selected the same two-variable model that was previously identified (SL and N/Ca). 


\section{Results and Discussion}

Comparisons of bitter pit incidence, fruit nutrient levels, $C D$, and terminal $S L$. Means for all variables by year and orchard are presented in Table 1. Regression analyses over the multiple years of the project indicated bitter pit was very highly correlated to the fruit peel ratios of $\mathrm{N} / \mathrm{Ca}, \mathrm{K} / \mathrm{Ca}, \mathrm{Mg} / \mathrm{Ca},(\mathrm{K}+\mathrm{Mg}) /$ $\mathrm{Ca},(\mathrm{N}+\mathrm{K}+\mathrm{Mg}) / \mathrm{Ca}$ and $(\mathrm{Mg}+\mathrm{K}+\mathrm{N}) / \mathrm{Ca})-38$ (accumulated ratio) and inversely correlated to the level of $\mathrm{Ca}$ (Table 2). Bitter pit incidence increased with increasing SL and decreased with decreasing CD (Table 2). Soluble solid concentration and firmness were not correlated with bitter pit in any of the years of the study, and fruit weight was correlated with bitter pit in 2016 only, with larger fruit having more bitter pit (data not shown).

The percentage of fruit developing bitter pit varied depending on year, orchard, and tree within an orchard. When averaged over the nine trees within an orchard, the average percentage of fruit developing bitter pit varied from $0 \%$ to $22 \%, 3 \%$ to $21 \%$, and $0 \%$ to $74 \%$ in 2014,2015 , and 2016 , respectively (Table 1). The variation within orchards was not consistent. For example, in 2014, all nine trees in Orchard 6 had no bitter pit, whereas in 2016, the percentage of fruit on individual trees developing bitter pit in Orchard number 4 varied from $0 \%$ to $100 \%$ (data not shown). Bitter pit was most severe in 2016, but even in this severe year one orchard had no bitter pit. Considering the entire data set, CD varied from 1.66 to 5.09 fruit $/ \mathrm{cm}^{2}$ trunk cross-sectional area. Average SL varied from 9.8 to $38.7 \mathrm{~cm}$, and shoots were shortest in 2014. Fruit peel N concentrations ranged from $0.28 \%$ to $0.50 \%$ and were lowest in 2015. Peel K concentrations varied from $0.59 \%$ to $1.17 \%$ and tended to be highest in 2014. Peel concentrations of $\mathrm{Mg}$ and $\mathrm{Ca}$ ranged from $0.074 \%$ to $0.109 \%$ and $0.022 \%$ to $0.050 \%$, respectively, and differences between years were small. The ratio of $\mathrm{N}$ to $\mathrm{Ca}$ in the peel varied from 7.2 to 23.2 and tended to be lowest in 2015. The ratios of $(\mathrm{Mg}+\mathrm{K}) / \mathrm{Ca}$, and $(\mathrm{Mg}+\mathrm{K}+\mathrm{N}) / \mathrm{Ca}$ and accumulated ratio ranged from 13.4 to 53.2 , 22.1 to 76.5 , and -15.9 to 38.4 , respectively.

Correlations for individual and multiple years. The linear correlations among variables were usually similar for all 3 years (Table 2). Bitter pit was significantly correlated with most variables in Table 2 every year, but correlation coefficients were lowest in 2015 and highest in 2016 (Table 2). In 2014 and 2015 , bitter pit was not correlated with $\mathrm{N}$ and $\mathrm{Mg}$ peel concentrations. Bitter pit was negatively correlated only with $\mathrm{CD}$ and peel $\mathrm{Ca}$ concentration every year. Within a season, the various ratios of elements were similarly correlated with bitter pit. Correlation coefficients ranged from 0.56 to $0.63,0.47$ to 0.51 , and 0.81 to 0.88 in 2014, 2015, and 2016, respectively. Ratios of concentrations of elements in the peel were more highly correlated with bitter pit than were concentrations of individual elements in the peel. Bitter pit was more highly correlated with CD and SL than with concentrations of individual elements in the peel. CD was positively correlated with peel $\mathrm{Ca}$ concentration. Peel $\mathrm{N}$ and $\mathrm{Mg}$ concentrations were negatively correlated with CD. Shoot length was not consistently correlated with peel $\mathrm{N}, \mathrm{Mg}$, or $\mathrm{P}$ and was negatively correlated with only $\mathrm{Ca}$.

The best multiple regression models developed using data from individual years indicate bitter pit incidence was related to different predictor variables each year (Table 3). In 2014, N, CD, Ca, and their

Table 1. Bitter pit (\%), crop density (CD, fruit $/ \mathrm{cm}^{2}$ trunk cross-sectional area), average shoot length (SL, $\left.\mathrm{cm}\right)$, and peel nutrient levels for six commercial 'Honeycrisp' orchards over 3 years. ${ }^{\mathrm{z}}$

\begin{tabular}{|c|c|c|c|c|c|c|c|c|c|c|c|c|}
\hline$\overline{\mathrm{Yr}}$ & Orchard & Bitter pit & $\mathrm{CD}$ & $\mathrm{SL}$ & $\mathrm{N}(\%)$ & $\mathrm{K}(\%)$ & $\operatorname{Mg}(\%)$ & $\mathrm{Ca}(\%)$ & $\mathrm{N} / \mathrm{Ca}$ & $(\mathrm{Mg}+\mathrm{K}) / \mathrm{Ca}$ & $(\mathrm{Mg}+\mathrm{K}+\mathrm{N}) / \mathrm{Ca}$ & Accum. ratio \\
\hline \multirow[t]{6}{*}{$\overline{2014}$} & 1 & 22.3 & 1.66 & 16.61 & 0.50 & 1.05 & 0.087 & 0.034 & 15.16 & 34.26 & 50.61 & 11.42 \\
\hline & 2 & 7.2 & 4.29 & 12.10 & 0.50 & 1.04 & 0.109 & 0.044 & 11.72 & 27.13 & 39.47 & 0.85 \\
\hline & 3 & 9.1 & 3.29 & 14.51 & 0.36 & 1.14 & 0.088 & 0.037 & 10.74 & 37.66 & 49.95 & 10.39 \\
\hline & 4 & 15.7 & 2.60 & 18.57 & 0.41 & 1.17 & 0.096 & 0.046 & 9.27 & 28.52 & 37.81 & -0.21 \\
\hline & 5 & 6.3 & 1.83 & 17.67 & 0.42 & 1.06 & 0.096 & 0.040 & 10.12 & 34.88 & 47.12 & 0.28 \\
\hline & 6 & 0.0 & 3.61 & 9.81 & 0.42 & 0.85 & 0.806 & 0.043 & 10.61 & 23.68 & 32.40 & -3.71 \\
\hline \multirow[t]{6}{*}{2015} & 1 & 15.6 & 2.42 & 28.44 & 0.39 & 0.62 & 0.093 & 0.050 & 8.09 & 14.70 & 22.80 & -15.21 \\
\hline & 2 & 20.6 & 1.82 & 29.46 & 0.34 & 1.13 & 0.085 & 0.032 & 10.63 & 38.46 & 48.98 & 11.09 \\
\hline & 3 & 17.2 & 2.69 & 30.40 & 0.28 & 0.86 & 0.093 & 0.036 & 8.23 & 28.44 & 36.73 & -1.33 \\
\hline & 4 & 17.8 & 1.72 & 30.90 & 0.35 & 0.96 & 0.104 & 0.040 & 9.00 & 27.84 & 37.01 & -1.16 \\
\hline & 5 & 2.8 & 2.94 & 30.99 & 0.30 & 0.81 & 0.094 & 0.042 & 7.19 & 31.85 & 29.09 & -8.96 \\
\hline & 6 & 4.4 & 1.91 & 32.61 & 0.32 & 0.75 & 0.084 & 0.033 & 9.93 & 27.41 & 37.59 & -0.66 \\
\hline \multirow[t]{6}{*}{2016} & 1 & 51.7 & 2.32 & 28.57 & 0.39 & 1.08 & 0.083 & 0.031 & 13.71 & 41.02 & 54.79 & 16.73 \\
\hline & 2 & 48.9 & 3.28 & 22.87 & 0.46 & 0.95 & 0.080 & 0.033 & 14.97 & 34.12 & 48.97 & 11.10 \\
\hline & 3 & 73.9 & 2.99 & 37.43 & 0.48 & 1.02 & 0.092 & 0.022 & 23.22 & 53.20 & 76.51 & 38.41 \\
\hline & 4 & 35.0 & 4.34 & 24.70 & 0.42 & 0.99 & 0.079 & 0.040 & 11.28 & 28.52 & 39.74 & 1.80 \\
\hline & 5 & 39.4 & 2.94 & 38.69 & 0.40 & 0.96 & 0.081 & 0.035 & 11.87 & 31.19 & 43.02 & 5.07 \\
\hline & 6 & 0.0 & 5.09 & 17.76 & 0.43 & 0.59 & 0.074 & 0.050 & 8.69 & 13.36 & 22.09 & -15.95 \\
\hline
\end{tabular}

${ }^{\mathrm{z}}$ Values are means of nine trees per orchard with varying crop densities.

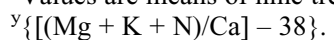

Table 2. Correlation coefficients indicating the linear relationship between bitter pit $(\%)$, crop density $\left(\mathrm{CD}\right.$, fruit/ $\mathrm{cm}^{2}$ trunk cross-sectional area), shoot length $(\mathrm{cm})$, and various concentrations of 'Honeycrisp' fruit peel nutrients $(\%)$ measured 3 weeks before harvest for three consecutive years $(r$-values greater than 0.273 and 0.354 are significant at the $5 \%$ and $1 \%$ levels, respectively, $n=54$ ).

\begin{tabular}{|c|c|c|c|c|c|c|c|c|c|}
\hline \multirow[b]{2}{*}{ Variable } & \multicolumn{3}{|c|}{ Bitter pit } & \multicolumn{3}{|c|}{$\mathrm{CD}$} & \multicolumn{3}{|c|}{ Shoot length } \\
\hline & 2014 & 2015 & 2016 & 2014 & 2015 & 2016 & 2014 & 2015 & 2016 \\
\hline$\overline{\mathrm{CD}}$ & -0.55 & -0.50 & -0.73 & - & - & - & -0.64 & -0.69 & -0.71 \\
\hline SL & 0.52 & 0.44 & 0.72 & -0.64 & -0.69 & -0.71 & - & - & - \\
\hline $\mathrm{N}$ & 0.29 & 0.03 & 0.14 & -0.02 & 0.05 & 0.04 & 0.02 & -0.14 & 0.01 \\
\hline K & 0.52 & 0.32 & 0.54 & -0.43 & -0.43 & -0.38 & 0.65 & 0.31 & 0.34 \\
\hline $\mathrm{Mg}$ & 0.09 & 0.11 & 0.61 & 0.14 & 0.07 & -0.42 & 0.09 & 0.06 & 0.56 \\
\hline $\mathrm{Ca}$ & -0.49 & -0.41 & -0.88 & 0.49 & 0.59 & 0.75 & -0.52 & -0.56 & -0.72 \\
\hline $\mathrm{P}$ & 0.62 & 0.45 & 0.50 & -0.70 & -0.58 & -0.43 & 0.72 & 0.45 & 0.16 \\
\hline $\mathrm{Mg} / \mathrm{Ca}$ & 0.56 & 0.51 & 0.86 & -0.43 & -0.57 & -0.65 & 0.50 & 0.61 & 0.72 \\
\hline $\mathrm{K} / \mathrm{Ca}$ & 0.56 & 0.49 & 0.88 & -0.50 & -0.56 & -0.68 & 0.55 & 0.47 & 0.68 \\
\hline $\mathrm{N} / \mathrm{Ca}$ & 0.63 & 0.47 & 0.81 & -0.47 & -0.58 & -0.61 & 0.40 & 0.50 & 0.65 \\
\hline$(\mathrm{Mg}+\mathrm{K}) / \mathrm{Ca}$ & 0.56 & 0.46 & 0.88 & -0.50 & -0.57 & -0.68 & 0.55 & 0.48 & 0.68 \\
\hline$(\mathrm{Mg}+\mathrm{K}+\mathrm{N}) / \mathrm{Ca}$ & 0.60 & 0.47 & 0.87 & -0.50 & -0.60 & -0.67 & 0.52 & 0.51 & 0.69 \\
\hline Accum ratio & 0.61 & 0.48 & 0.88 & -0.52 & -0.59 & -0.67 & 0.54 & 0.50 & 0.68 \\
\hline
\end{tabular}

SL $=$ shoot length. 
Table 3. Best multiple regression models for predicting the percentage of fruit on a tree likely to develop bitter pit (BP) in 2014, 2015, and 2016. All $R^{2}$ values are significant at the $0.01 \%$ level, $n=54$.

\begin{tabular}{llr}
\hline Yr & \multicolumn{1}{c}{ Model } & $R^{2}$ \\
\hline 2014 & $\mathrm{BP}=43.5+111.4 * \mathrm{~N}+2.5 *(\mathrm{~N} / \mathrm{Ca})+1.9 * \mathrm{CD}-1.6 *(\mathrm{~N} / \mathrm{Ca} * \mathrm{CD})-0.56 *(\mathrm{~K} / \mathrm{Ca})+4.9 *(\mathrm{~K} / \mathrm{Ca} * \mathrm{CD})$ & 0.61 \\
2015 & $\mathrm{BP}=0.027-0.033 * \mathrm{CD}+0.07 *(\mathrm{Mg} / \mathrm{Ca})$ & 0.56 \\
2016 & $\mathrm{BP}=-37.3+0.71 * \mathrm{SL}+1.76 *(\mathrm{Mg}+\mathrm{K}) / \mathrm{Ca}$ & 0.29 \\
\hline
\end{tabular}
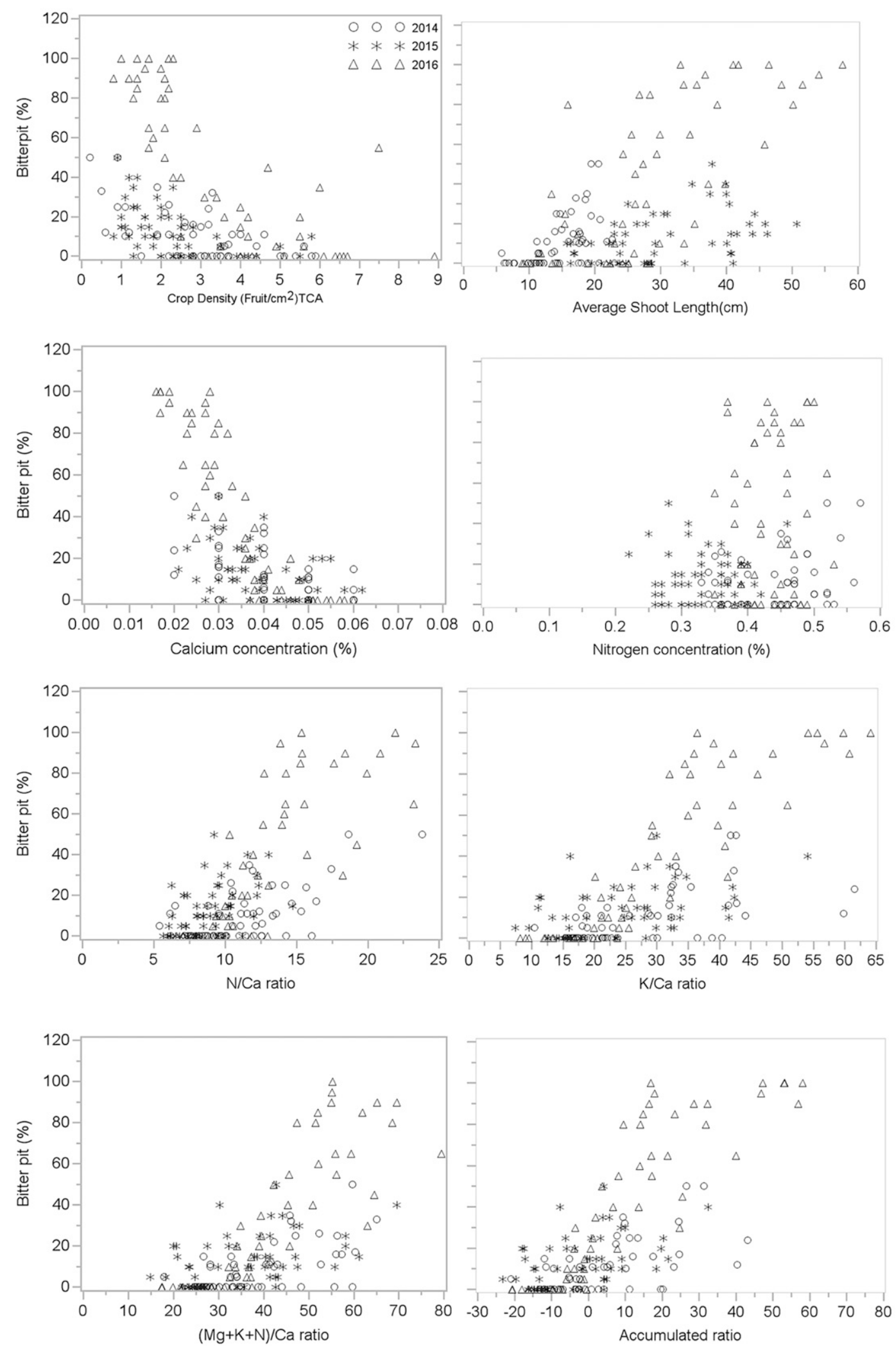

Fig. 1. Scatter plots showing the relationship between the percentage of fruit developing bitter pit and concentrations of nutrients in the peel at the calyx end of 'Honeycrisp' apples over three seasons. Each observation represents a single tree replicate. 
interactions were important predictors of bitter pit, and the $R^{2}$ was 0.61 . In 2015 , the only two predictors that were significant were $\mathrm{CD}$ and $\mathrm{Mg} / \mathrm{Ca}$, and the $R^{2}$ was only 0.32 . In 2016, the best model contained SL and $(\mathrm{Mg}+\mathrm{K}) / \mathrm{Ca}$, and the $R^{2}$ was 0.80 . When the best model developed with the 2014 data set was fit to the data set for 2015 , none of the variables were significant $(P>0.03)$, and for the 2016 data set, only one variable $(\mathrm{K} / \mathrm{Ca})$ was significant at the $5 \%$ level. The variable results from year to year indicate that for unknown reasons bitter pit is related to different variables each year, and models based on data collected for a single season are not very robust even when data are collected from several different orchards. Variables that may influence bitter pit, but were not recorded in this study, may include factors such as temperature and soil moisture.

From the scatter plots in Fig. 1, it is obvious that bitter pit incidence was highest in 2016. In 2014 and 2015, many trees had little or no bitter pit regardless of peel mineral concentrations, CD, or SL. For any given level of an individual predictor variable, the range of observed bitter pit was quite variable. For example, in 2016, fruit on trees with an average SL of $32 \mathrm{~cm}$ developed $10 \%$ to $100 \%$ bitter pit; fruit on trees with a CD of 2.3 had $10 \%$ to $100 \%$ bitter pit; and fruit on trees with a $(\mathrm{Mg}+\mathrm{K}) / \mathrm{Ca}$ value of 45 had $30 \%$ to $90 \%$ bitter pit. Therefore, in any given year bitter pit severity was likely related to some variable(s) that we did not measure. The highest correlation coefficients were associated with the ratios of $\mathrm{Mg}$ and/or $\mathrm{K}$ and/or $\mathrm{N}$ to Ca (Table 2), but the scatter plots for bitter pit vs. all potential predictor variables showed a higher degree of variation than expected (Fig. 1). Bitter pit seemed to be best related to $\mathrm{N} / \mathrm{Ca}$ with the ratios being 6-16 in trees with no bitter pit and 16-25 in trees with $100 \%$ bitter pit (Fig. 1).

Development of a predictive model. The object of multiple regression is to identify a parsimonious model - a model with a high level of explanation or prediction with as few predictor variables as possible. Models with too few variables may produce biased estimates. When a model contains too many variables the regression coefficients, $P$ values, and $R^{2}$ may be misleading, and the predictive performance of the model may be poor. The statistics used to evaluate the best three models with a given number of variables are presented in Table 4 . As the number of predictor variables in a model increases, the $R^{2}$ value always increases. The adjusted $R^{2}$ is adjusted for the number of predictors in the model and increases only if the new term improves the model more than would be expected by chance. Mallow's $C_{\mathrm{p}}$ statistic compares the precision and bias of the full model to models with a subset of predictors, and small values of $C_{\mathrm{p}}$ indicate that the model is relatively precise with small variance. Models with $C_{\mathrm{p}}$ values greater than the number of predictors may be overfit and candidate models with small $C_{\mathrm{p}}$ values are preferred. AIC is a measure of the relative quality of a model in a subset of models and can be used to assess the model fit penalized for the number of variables in the model. Models with the smallest AIC values are preferred. The final criterion that was used was the model MSE, and small values of MSE are preferred. Generally, all of these criteria change together as one evaluates models with increasing numbers of predictor variables, but they can be used to compare models with similar numbers of predictor variables to aid in selecting the best model.

When data for the 3 years were pooled, the best model with a single predictor variable was N/Ca (Table 4). The accumulated ratio was very highly correlated to $\mathrm{K} / \mathrm{Ca}, \mathrm{Mg} / \mathrm{Ca}$, and $(\mathrm{Mg}+\mathrm{K}) / \mathrm{Ca}$ and therefore was no better than the other ratios. The accumulated ratio and $(\mathrm{Mg}+\mathrm{K}+\mathrm{N}) / \mathrm{Ca}$ had similar $R^{2}$ values most of the time and based on the $C_{\mathrm{p}}$ statistic, AIC values and MSE were similar predictors. Adding SL to the model with N/Ca increased the $R^{2}$ from 0.58 to 0.68 and values for $C_{\mathrm{p}}$, AIC and MSE decreased dramatically. Shoot length and $\mathrm{N} / \mathrm{Ca}$ were the only variables common to all models containing more than two variables. Adding up to five additional predictors to the model increased the $R^{2}$ to 0.73 , but the minimum values for $C_{\mathrm{p}}$ and $\mathrm{AIC}$ were associated with the model with six predictors. In addition to N/Ca and SL, predictors that were consistently selected, in order of importance included $\mathrm{P}, \mathrm{B}, \mathrm{S}$, $\mathrm{Ca}$, and $\mathrm{Mg} / \mathrm{Ca}$. Based on output from the COLLINOINT option, $\mathrm{N}$ and N/Ca, N/Ca and $\mathrm{Ca}$, and $\mathrm{N} / \mathrm{Ca}$ and $\mathrm{Mg} / \mathrm{Ca}$ were collinear. Models with more than five predictors were considered nondesirable because they

Table 4. The best three multiple regression models for one to seven regressor variables, along with fit statistics using data from nine trees in each of six orchards for 3 years $(n=161)$. For comparative purposes, the best models containing accumulated ratio and $(\mathrm{Mg}+\mathrm{K}+\mathrm{N}) / \mathrm{Ca}$ are also shown.

\begin{tabular}{|c|c|c|c|c|c|c|}
\hline No. of variables & Model variables ${ }^{z}$ & $R^{2}$ & $\operatorname{Adj} R^{2}$ & $C_{\mathrm{p}}$ & $\overline{\mathrm{AIC}}$ & $\overline{M S E}$ \\
\hline$\overline{1}$ & $\mathrm{~N} / \mathrm{Ca}$ & 0.58 & 0.58 & 69.7 & 935.5 & 329.6 \\
\hline 1 & accum. ratio & 0.55 & 0.55 & 87.7 & 947.8 & 355.8 \\
\hline 1 & $\mathrm{Mg} / \mathrm{Ca}$ & 0.53 & 0.52 & 100.8 & 956.2 & 374.9 \\
\hline 1 & $(\mathrm{Mg}+\mathrm{K}+\mathrm{N}) / \mathrm{Ca}$ & 0.52 & 0.51 & 108.3 & 959.3 & 382.2 \\
\hline 2 & $\mathrm{~N} / \mathrm{Ca}, \mathrm{SL}^{\mathrm{y}}$ & 0.68 & 0.68 & 18.7 & 894.6 & 254.1 \\
\hline 2 & SL, accum. ratio & 0.62 & 0.62 & 49.3 & 920.8 & 299.0 \\
\hline 2 & $\mathrm{~N} / \mathrm{Ca}, \mathrm{Al}$ & 0.62 & 0.62 & 49.9 & 921.2 & 299.9 \\
\hline 2 & $(\mathrm{Mg}+\mathrm{K}+\mathrm{N}) / \mathrm{Ca}, \mathrm{SL}$ & 0.60 & 0.59 & 62.9 & 929.6 & 315.8 \\
\hline 3 & $\mathrm{~N} / \mathrm{Ca}, \mathrm{SL}, \mathrm{P}$ & 0.69 & 0.69 & 14.4 & 890.7 & 246.6 \\
\hline 3 & $\mathrm{~N} / \mathrm{Ca}, \mathrm{SL}, \mathrm{Mn}$ & 0.69 & 0.69 & 16.0 & 892.2 & 248.9 \\
\hline 3 & $\mathrm{~N} / \mathrm{Ca}, \mathrm{SL}, \mathrm{Al}$ & 0.69 & 0.68 & 17.2 & 893.3 & 250.7 \\
\hline 3 & $\mathrm{~N} / \mathrm{Ca}, \mathrm{SL}$, accum. ratio & 0.68 & 0.68 & 21.4 & 895.7 & 254.4 \\
\hline 3 & $(\mathrm{~N} / \mathrm{Ca}), \mathrm{SL},(\mathrm{Mg}+\mathrm{K}+\mathrm{N}) / \mathrm{Ca}$ & 0.68 & 0.68 & 22.0 & 896.2 & 255.3 \\
\hline 4 & $\mathrm{~N} / \mathrm{Ca}, \mathrm{SL} \mathrm{P}, \mathrm{B}$ & 0.71 & 0.70 & 5.4 & 881.7 & 231.8 \\
\hline 4 & $\mathrm{~N} / \mathrm{Ca}, \mathrm{SL}, \mathrm{P}, \mathrm{Al}$ & 0.70 & 0.69 & 11.8 & 888.2 & 241.3 \\
\hline 4 & $\mathrm{~N} / \mathrm{Ca}, \mathrm{SL}, \mathrm{P}, \mathrm{Na}$ & 0.70 & 0.69 & 12.8 & 889.2 & 242.8 \\
\hline 4 & $\mathrm{~N} / \mathrm{Ca}, \mathrm{SL}, \mathrm{P},(\mathrm{Mg}+\mathrm{K}+\mathrm{N}) / \mathrm{Ca}$ & 0.69 & 0.69 & 16.1 & 890.9 & 245.3 \\
\hline 4 & $\mathrm{~N} / \mathrm{Ca}, \mathrm{SL}, \mathrm{P}$, accum. ratio & 0.69 & 0.69 & 17.5 & 892.2 & 247.4 \\
\hline 5 & $\mathrm{~N} / \mathrm{Ca}, \mathrm{SL}, \mathrm{P}, \mathrm{B}, \mathrm{S}$ & 0.72 & 0.71 & 5.08 & 881.3 & 229.8 \\
\hline 5 & $\mathrm{~N} / \mathrm{Ca}, \mathrm{SL}, \mathrm{P}, \mathrm{B}, \mathrm{Ca}$ & 0.72 & 0.71 & 5.56 & 881.8 & 230.6 \\
\hline 5 & $\mathrm{~N} / \mathrm{Ca}, \mathrm{SL}, \mathrm{P}, \mathrm{B}, \mathrm{Mg} / \mathrm{Ca}$ & 0.71 & 0.70 & 6.56 & 882.9 & 232.1 \\
\hline 5 & $\mathrm{~N} / \mathrm{Ca}, \mathrm{SL}, \mathrm{P}, \mathrm{B},(\mathrm{Mg}+\mathrm{K}+\mathrm{N}) / \mathrm{Ca}$ & 0.71 & 0.70 & 8.66 & 883.4 & 232.9 \\
\hline 5 & $\mathrm{Ca}, \mathrm{SL}, \mathrm{N}, \mathrm{P}$, accum. ratio & 0.71 & 0.70 & 8.93 & 883.7 & 233.3 \\
\hline 6 & $\mathrm{~N} / \mathrm{Ca}, \mathrm{SL}, \mathrm{P}, \mathrm{B}, \mathrm{S}, \mathrm{Ca}$ & 0.72 & 0.71 & 2.85 & 878.8 & 225.0 \\
\hline 6 & $\mathrm{~N} / \mathrm{Ca}, \mathrm{SL}, \mathrm{P}, \mathrm{B}, \mathrm{S} \mathrm{Mg} / \mathrm{Ca}$ & 0.72 & 0.71 & 4.97 & 881.1 & 228.2 \\
\hline 6 & $\mathrm{~N} / \mathrm{Ca}, \mathrm{SL}, \mathrm{P}, \mathrm{B}, \mathrm{S}, \mathrm{N}$ & 0.72 & 0.71 & 5.88 & 882.1 & 229.5 \\
\hline 6 & $\mathrm{~N} / \mathrm{Ca}, \mathrm{SL}, \mathrm{P}, \mathrm{B}, \mathrm{Ca},(\mathrm{Mg}+\mathrm{K}+\mathrm{N}) / \mathrm{Ca}$ & 0.72 & 0.71 & 7.95 & 882.7 & 230.4 \\
\hline 7 & $\mathrm{~N} / \mathrm{Ca}, \mathrm{SL}, \mathrm{P}, \mathrm{B}, \mathrm{Ca}$, accum. ratio & 0.71 & 0.71 & 8.20 & 882.9 & 230.8 \\
\hline 7 & N/Ca, SL, P, B, S, Ca, K/Ca & 0.73 & 0.71 & 3.80 & 879.7 & 224.9 \\
\hline 7 & $\mathrm{~N} / \mathrm{Ca}, \mathrm{SL}, \mathrm{P}, \mathrm{B}, \mathrm{S}, \mathrm{Ca},(\mathrm{Mg}+\mathrm{K}) / \mathrm{Ca}$ & 0.73 & 0.71 & 3.97 & 879.9 & 225.1 \\
\hline 7 & N/Ca, SL, P, B, S, Ca, accum. Ratio & 0.73 & 0.71 & 3.97 & 879.9 & 225.1 \\
\hline 7 & $\mathrm{~N} / \mathrm{Ca}, \mathrm{SL}, \mathrm{P}, \mathrm{B}, \mathrm{S}, \mathrm{Ca},(\mathrm{Mg}+\mathrm{K}+\mathrm{N}) / \mathrm{Ca}$ & 0.72 & 0.71 & 6.04 & 880.6 & 226.1 \\
\hline
\end{tabular}

${ }^{\mathrm{z}}$ Models were obtained with the RSQUARE option in SAS's PROC REG.

${ }^{\mathrm{y}_{\mathrm{SL}}}=$ shoot length $(\mathrm{cm})$.

$\mathrm{AIC}=$ Akaike information criterion; $C_{\mathrm{p}}=$ crop density; $\mathrm{MSE}=$ mean square error.

Table 5. The best one-, two-, three-, and four-variable multiple regression models for predicting the percentage of 'Honeycrisp' apples on a tree that will develop bitter pit after storage based on average shoot length (SL, cm) and peel nutritional concentrations (\%) sampled 3 weeks before harvest. All $R^{2}$ values are significant $(P<0.0001, n=161)$.

\begin{tabular}{|c|c|c|c|c|c|c|}
\hline & Intercept & $\mathrm{N} / \mathrm{Ca}$ & $\mathrm{SL}$ & $\mathrm{P}$ & $\mathrm{B}$ & $R^{2}$ \\
\hline Parameter estimates & -30.97 & 4.628 & - & - & - & 0.5830 \\
\hline Standard errors of the estimates & 3.81 & 4.628 & - & - & - & \\
\hline Parameter estimates & -42.54 & 3.895 & 0.810 & - & - & 0.6805 \\
\hline Standard errors of the estimates & 3.73 & 0.292 & 0.117 & - & 一 & \\
\hline Parameter estimates & -54.91 & 3.772 & 0.748 & 186.19 & - & 0.6920 \\
\hline Standard errors of the estimates & 6.31 & 0.292 & 0.118 & 77.12 & - & \\
\hline Parameter estimates & -46.82 & 4.173 & 0.583 & 363.32 & -0.785 & 0.7123 \\
\hline Standard errors of the estimates & 6.58 & 0.308 & 0.125 & 91.89 & 0.237 & \\
\hline
\end{tabular}


contained variables that were collinear. The best two-variable model $(\mathrm{N} / \mathrm{Ca}+\mathrm{SL})$ and the best four-variable model $(\mathrm{N} / \mathrm{Ca}+\mathrm{SL}+\mathrm{P}+\mathrm{B})$ had adjusted $R^{2}$ s of 0.68 and 0.70 , respectively. We selected the two-variable model because it explained only $2 \%$ less variation than the more complicated four-variable model. Parameter estimates and standard errors of the estimates for the best one-, two-, three-, and four-variable models are presented in Table 5 in case future researchers would like to compare their models with ours. Predicted bitter pit values obtained with PROC SCORE were plotted against the observed values for the best two-variable model containing SL and N/Ca (Fig. 2). The regression model predicts quite well the percentage of fruit developing bitter pit on trees with less than $50 \%$ bitter pit, but the model underpredicts bitter pit for trees with higher levels of observed bitter pit.

Models with two predictor variables can sometimes be viewed as 3-dimensional plots, but these are often difficult to interpret. For ease of interpretation, the data set was partitioned into three subsets, with similar numbers of observations, based on average SL: short $<18.0 \mathrm{~cm}$; medium 18.01 to $27.99 \mathrm{~cm}$; and long $>28 \mathrm{~cm}$ (Fig. 3). As average SL increased, the slope of the predicted line became steeper. Based on the slopes and the $R^{2}$ values, trees with long shoots were more influenced by the ratio N/Ca than trees with short shoots. Therefore, apple growers may want to evaluate SL when considering $\mathrm{Ca}$ application rates during the season. The model developed from the 3-year data set indicates that $68 \%$ of the variation in the percentage of apples on individual trees that develop bitter pit can be accounted for by estimating average SL from 10 shoots per tree and measuring the $\mathrm{N} / \mathrm{Ca}$ ratio from peels of 15 fruit per tree. Based on the predicted lines in Fig. 3, for no more than 20\% bitter pit, trees with short, medium, and long shoots should have $\mathrm{N} / \mathrm{Ca}$ ratios no greater than 16 , 12, and 9. For the commercial goal of less than $5 \%$ bitter pit, the respective $\mathrm{N} / \mathrm{Ca}$ ratios are $8.5,7.6$, and 5.75 .

Implications for managing bitter pit in 'Honeycrisp' orchards. The two-variable model based on 3 years of research in commercial 'Honeycrisp' orchards with varying levels of bitter pit has several implications for the development of best management practices in the orchard. Growers have longunderstood the importance of a multifaceted approach for controlling Ca-related disorders in bitter pit-prone cultivars, but in the case of 'Honeycrisp', it has been difficult to ascertain which practices are most important relative to its high susceptibility to the disorder. The two-variable model suggests the focus should be on managing terminal shoot growth and increasing the ratio of $\mathrm{Ca}$ to $\mathrm{N}$ in the fruit.

Managing terminal shoot growth begins with orchard site selection and preparation. Research by Cheng (2016) indicates although it is important to encourage early tree growth of 'Honeycrisp', it is imperative to avoid any soil conditions or practices that will promote excessive shoot growth during the bearing years. Growth suppression is an option for established blocks of 'Honeycrisp' (Mitcham, 2008; Silveira et al., 2012), but the twovariable model suggests growers give greater attention to optimizing factors that affect tree vigor before planting 'Honeycrisp'. Best management of $\mathrm{Ca}$ relative to $\mathrm{N}$ also begins before planting, and lime applications in the East often need to start 2 years before planting to adjust the $\mathrm{pH}$ to 6.5 (Baugher and Singh, 1989; Cheng, 2016). Leaf analysis of Mid-Atlantic orchards historically indicates $\mathrm{N}$ rates should be reduced rather than increased (Baugher and Singha, 1985). The prediction model highlights the value of annual leaf analysis in 'Honeycrisp' orchards for maintaining optimal $\mathrm{N}$ levels. Although not included in the two-factor model, statistical analyses demonstrated slightly better predictions with the addition of $\mathrm{Mg}$ and/ or $\mathrm{K}$ to $\mathrm{Ca}$ ratios, which is in agreement with other studies (Amarante et al., 2013; De Freitas et al., 2015). Fruit peel analysis shows potential as an additional tool for balancing nutrient ratios.

As reported by Al Shoffe et al. (2014) and Cheng (2016), Ca levels in 'Honeycrisp' fruit are inherently lower than in other cultivars. Peel $\mathrm{Ca}$ levels of $0.04 \%$ to $0.05 \%$ were associated with the lowest bitter pit levels in 'Honeycrisp'. Whereas many apple cultivars have fruit peel $\mathrm{Ca}$ levels of $0.05 \%$ to $0.06 \%$, 'Honeycrisp' often only had a peel Ca level of $0.03 \%$. Total actual $\mathrm{Ca}$ applied per season was inversely related to bitter pit, with the best suppression of bitter pit being with 9.0 to $14.6 \mathrm{~kg} \cdot \mathrm{ha}^{-1}$ and the source being $\mathrm{CaCl}_{2} \quad(95 \%$ confidence level, data not shown). This finding is in agreement with field research (Biggs and Peck, 2015) that indicated actual $\mathrm{Ca}$ applications to 'Honeycrisp' should be as high as $26.3 \mathrm{~kg} \cdot \mathrm{ha}^{-1}$ per season and several studies that compared foliar Ca products (Biggs and Peck, 2015. Rosenberger et al., 2004).

Crop load effects varied by year and orchard, which indicated a need for sitespecific adjustments for bitter pit prevention. Crop density levels of 4 to 5 fruit $/ \mathrm{cm}^{2}$ trunk cross-sectional area were associated with less bitter pit. Peel $\mathrm{Ca}$ concentration was positively correlated with $\mathrm{CD}$. This is consistent with the findings of Ferguson and Watkins (1992) who reported lightly cropped trees had lower fruit $\mathrm{Ca}$ and higher fruit $\mathrm{K}$ concentrations than heavily cropped trees. Research by Telias et al. (2006) demonstrated similar results with 'Honeycrisp'. Ferguson (2001) reported the bitter pit association with low crop load was not directly related to fruit size and was more likely due to differences in fruit to leaf ratios and fruit position on the tree, with fruit in the upper canopy tending to have lower Ca levels.

Implications for post-harvest handling of 'Honeycrisp'. Predictive schemes for segregating fruit for short- vs. long-term storage based on bitter pit potential have generally involved a one-variable fruit $\mathrm{Ca}$ model or

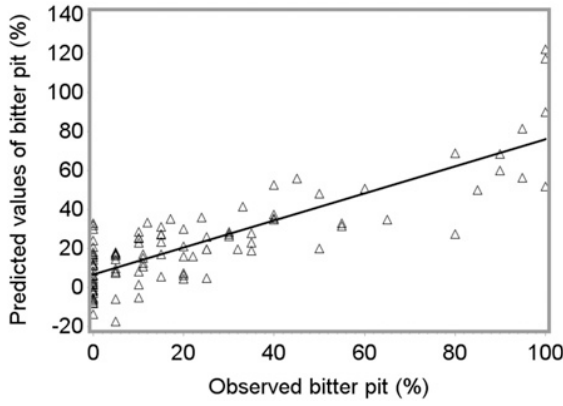

Fig. 2. Relationship between bitter pit (\% observed) and predicted values generated with SAS's PROC SCORE. Regression equation for the three-year data set $(n=161)$ : Bitter pit $(\%)=-44.29+0.802 * \mathrm{SL}+4.13 *(\mathrm{~N} / \mathrm{Ca})$ where $\mathrm{SL}=$ average terminal shoot length $(\mathrm{cm})$ on each tree, and $(\mathrm{N} / \mathrm{Ca})$ is the ratio of nitrogen to calcium in the peel at the calyx end of 'Honeycrisp' apples for three seasons.

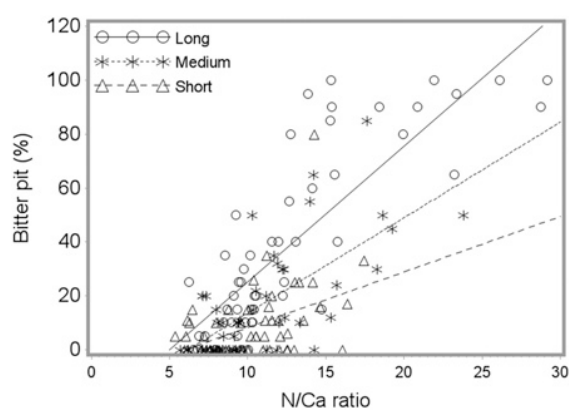

Fig. 3. Relationships between bitter pit (BP) and $\mathrm{N} / \mathrm{Ca}$ ratio for 'Honeycrisp' apple trees with short, medium, and long shoots. Shoot length is the average terminal shoot length of 10 shoots per tree. The $\mathrm{N} / \mathrm{Ca}$ ratio is the ratio of nitrogen to calcium in the peel at the calyx end of the apples over three years. Regression equations: short shoots $-\% \mathrm{BP}=-12.40+2.06 *(\mathrm{~N} / \mathrm{Ca})$ $\left(R^{2}=0.19, P=0.0005, n=58\right)$; medium shoots: $\% \mathrm{BP}=-2.01+3.55 *(\mathrm{~N} / \mathrm{Ca})\left(R^{2}=0.47, P<\right.$ $0.0001, n=50)$; and long shoots $-\% \mathrm{BP}=$ $-22.46+4.80 *(\mathrm{~N} / \mathrm{Ca})\left(R^{2}=0.6897, P<\right.$ $0.0001, n=53$ )

more complex models using the ratios of fruit $\mathrm{Mg}$ and/or K and/or N to Ca (Dris et al., 1998; Ferguson et al., 1979; Lanauskas and Kvikliene, 2006; Hanson, 2012). To increase reliability of the results, fruit for nutrient analysis should be systematically sampled from the field rather than from the bin (Ferguson, 2001). Sampling fruit 3 weeks before harvest gives the analytical laboratory time to send fruit analysis reports to growers and packers before harvest, and research by Al Shoffe et al. (2014) showed no differences in nutrient levels between fruit peel sampled at harvest vs. 3 weeks before harvest. The 3 years of uniform trials in commercial 'Honeycrisp' orchards demonstrated a simple $\mathrm{N} / \mathrm{Ca}$ nutrient model could be strengthened by the addition of terminal SL measurements. These measurements can be obtained 3 weeks before harvest while collecting fruit for mineral analysis. For best results, shoots should be measured on the trees from which 
fruit are sampled, and current season shoots with moderate branch angles should be selected (avoiding strong vertical shoots or weak shoots hanging below a horizontal orientation). 'Honeycrisp' is a challenging cultivar to grow and to store, and research on tree and storage management is on-going.

\section{Literature Cited}

Al Shoffe, Y., J.F. Nock, and C.B. Watkins. 2014. Bitter pit and soft scald in 'Honeycrisp' during cold storage. HortScience 49:S203.

Amarante, C.V.T., J.P.G. Silveira, C.A. Steffens, and F.N. Paes. 2013. Tissue sampling method and mineral attributes to predict bitter pit occurrence in apple fruit: A multivariate approach. Acta Hort. 1012:1133-1139.

Baugher, T., J. Schupp, C. Lara, and C. Watkins. 2014. Crop load and fruit nutrient studies in commercial Honeycrisp orchards to determine best practices for minimizing bitter pit. PA Fruit News 94(2):37-40.

Baugher, T.A. and R.N. Singh. 1989. Evaluation of four soil amendments in ameliorating toxic conditions in three orchard subsoils. Appl. Agr. Res. 4(2):111-117.

Baugher, T.A. and S. Singha. 1985. Comparative seasonal variations in foliar nutrient concentrations of two apple and peach cultivars. Proc. WV Acad. Sci. 58:65-71.

Biggs, A.R. and G.M. Peck. 2015. Managing bitter pit in 'Honeycrisp' apples grown in the Mid-Atlantic United States with foliar-applied calcium chloride and some alternatives. HortTechnology 25:385-391.

Blanpied, G. D. and K. J. Silsby. 1992. Prediction of harvest date windows for apples. Cornell Coop. Ext. Bul. 221.
Cheng, L. 2016. Challenges and opportunities for Honeycrisp nutrient management. Proc. Empire State Expo. 15 June 2017. <http://www.hort. cornell.edu/expo/proceedings/2016/TreeFruit. $\% 20$ Challenged $\% 20$ and $\% 20$ opportunities $\% 20$ to $\% 20$ optimize $\% 20$ mineral\%20nutrition\%20of $\% 20$ Honeycrisp.Cheng.pdf $>$.

Cohen, R.A. 2006. Introducing the GLMSELECT PROCEDURE for model selection. Proc. 31st Ann. SAS ${ }^{\circledR}$ users group international Conf. SAS Institute Inc., Cary, NC.

Crassweller, R. and D. Smith. 2016. Nutritional analysis of new apple cultivars in high density plantings. PA Fruit News 96(2):21-22.

De Freitas, S.T., C.V.T. do Amarante, J.M. Labavitch, and E.J. Mitcham. 2010. Cellular approach to understand bitter pit development in apple fruit. Postharvest Biol. Technol. 57: 6-13.

De Freitas, S.T., C.V.T. do Amarante, and E.J. Mitcham. 2015. Mechanisms regulating apple cultivar susceptibility to bitter pit. Sci. Hort. 186:54-60.

Dris, R., R. Niskanen, and E. Fallahi. 1998. Nitrogen and calcium nutrition and fruit quality of commercial apple cultivars grown in Finland. J. Plant Nutr. 21:2389-2402.

Ferguson, I. 2001. Calcium in apple fruit. Proc. WA Tree Fruit Postharvest Conf., Wenatchee, WA. 15 June 2017. <http://postharvest.tfrec. wsu.edu/PC2001G.pdf>.

Ferguson, I.B., M.S. Reid, M. Prasad, and P.B. Levin. 1979. Calcium analysis and the prediction of bitter pit in apple fruit. N. Z. J. Agr. Res. 22:485-490.

Ferguson, I.B. and C.B. Watkins. 1992. Crop load affects mineral concentrations and incidence of bitter pit in 'Cox's Orange Pippin' apple fruit. J. Amer. Soc. Hort. Sci. 117:373-376.

Ferguson, I.B. and C.B. Watkins. 1989. Bitter pit in apple fruit. Hort. Rev. 11:289-355.
Freund, R.J. and R.C. Littell. 2000. SAS ${ }^{\circledR}$ system for regression. 3rd ed. SAS Institute Inc., Cary, NC.

Greene, D.W., J. Krupa, M. Vezina, and J.M. Clements. 2015. When to harvest Honeycrisp: A preliminary evaluation of methods? Fruit Notes 80(3): 1-5.

Hanson, M. 2012. Learn how to store Honeycrsip. Good Fruit Grower. 15 June 2017. <http:// www.goodfruit.com/learn-to-store-honeycrisp/>

Hocklin, B., S.D. Tyerman, R.A. Burton, and M. Gilliham. 2016. Fruit calcium: Transport and physiology. Front. Plant Sci. 7(569):1-17.

Lanauskas, J. and N. Kvikliene. 2006. Effect of calcium foliar application on some fruit quality characteristics of 'Sinap Orlovskij' apple. Agron. Res. 4:31-36.

Mitcham, E. 2008. A new approach to understand and control bitter pit in apple. Research Report, WA Tree Fruit Res. Commission. 15 June 2017. <http://jenny.tfrec.wsu.edu/wtfrc/ PDFfinalReports/2008FinalReports/Mitcham. pdf $>$.

Myers, R.H. 1990. Classical and modern regression with applications. 2nd ed. PWS-Kent, Boston, MA.

Rosenberger, D.A., J.R. Schupp, S.A. Hoying, L. Cheng, and C.B. Watkins. 2004. Controlling bitter pit in 'Honeycrisp' apples. HortTechnology 14:342-349.

Silveira, J.P.G., C.V.T. do Amarante, C.A. Steffens, A. Miqueloto, and J.M. Katsurayama. 2012. Inhibition of gibberellin synthesis reduces vegetative growth of apple trees and provides control of bitter pit in the fruit. Rev. Bras. Frutic. 34:328-335.

Telias, A., E. Hoover, C. Rosen, D. Bedford, and D. Cook. 2006. The effect of calcium sprays and fruit thinning on bitter pit incidence and calcium content in 'Honeycrisp' apple. J. Plant Nutr. 29:1941-1957. 